\title{
Hemopexin Synthesis in Vitro by Human Fetal Tissues
}

\author{
URSULA MULLER-EBERHARD, ${ }^{(32)}$ HAM HENG LIEM, KENDIS H. COX, AND THOMAS P. CONWAY \\ Department of Biochemistry, Scripps Clinic and Research Foundation, and the Department of Pediatrics, University \\ of California at San Diego, La Jolla, California, USA
}

Extract

Serum concentrations of hemopexin, transferrin, and albumin were measured for 12 fetuses between 14 and 36 weeks of gestational age. Hemopexin levels ranged from 7 to $64 \mu \mathrm{g} / \mathrm{ml}$, transferrin levels ranged from 280 to $928 \mu \mathrm{g} / \mathrm{ml}$, and albumin levels ranged from 13 to $59 \mathrm{mg} / \mathrm{ml}$. In general, the serum concentrations of these three proteins increased with advancing gestation.

Placenta, thymus, and colon did not incorporate ${ }^{14} \mathrm{C}$-labeled amino acids into hemopexin, transferrin, or albumin. By contrast, radioimmune precipitates for five culture supernatants of liver indicated significant synthesis of albumin and hemopexin. $\left[{ }^{14} \mathrm{C}\right]$ Albumin accounted for $22-73 \%$ and $\left[{ }^{14} \mathrm{C}\right]$ hemopexin 1.1 $4.2 \%$ of the total ${ }^{14} \mathrm{C}$-labeled proteins. In each instance, the $\left[{ }^{14} \mathrm{C}\right]$ transferrin was below $1 \%$ of the total ${ }^{14} \mathrm{C}$-labeled proteins.

\section{Speculation}

These data show considerable synthesis of albumin and hemopexin, but not transferrin, by the liver during fetal life. That hemopexin levels are lower in fetal than adult sera may reflect an increased requirement for heme disposal. Possibly, the increased turnover of hemopexin is related to the shortened lifespan of fetal in comparison with adult erythrocytes.

Mammalian serum contains two major porphyrin-binding proteins, hemopexin and albumin (11). Hemopexin has a higher binding affinity for metalloporphyrins than albumin (15) and is instrumental in the disposal of heme $(5,8,9,14,19)$. The liver is the site of hemopexin synthesis in rhesus monkeys (17), rabbits (17), and rats (12). In the present study, human fetal tissues were cultured and examined for the relative amounts of hemopexin, albumin, and transferrin produced.

\section{MATERIALS AND METHODS}

\section{FETAL TISSUES}

Serum samples of fetuses were obtained by heart puncture Tissuc cultures of liver, placenta, thymus, and colon of human fetuses, 12-25 weeks old, were developed by Dr. Peter F. Kohler (20), employing $\left[{ }^{14} \mathrm{C}\right]$ lysine and $\left[{ }^{14} \mathrm{C}\right]$ isoleucine (4). Culture supernatants were dialyzed against $0.015 \mathrm{M}$ phosphate-buffered saline (PBS), pH 7.4, lyophilized, dissolved in distilled water $(0.2-0.3 \mathrm{ml})$, shipped to La Jolla on Dry Ice, and stored at $-70^{\circ}$.

Tissues for absorption of antisera were obtained from fetuses within $5 \mathrm{hr}$ of saline-induced abortion. Small pieces of liver, placenta, thymus, and colon were passed through a stainless steel mesh with the aid of screen rakes. Cells were washed three times with PBS and mixed with 3 volumes antiserum $/ 1$ volume of cells. The mixtures were incubated at $37^{\circ}$ for $30 \mathrm{~min}$, at $4^{\circ}$ for $48 \mathrm{hr}$, and then the cells were removed by centrifugation at $1,200 \times g$ for 30 $\min$.

\section{DEVELOPMENT OF ANTISERA}

Hemopexin was purified from Cohn fraction IV-7, a gift of Squibb Pharmaceutical Co. (21), as previously reported (2). Albumin and transferrin were purchased from the Behringwerke (22), and bovine $\gamma$-globulin Fr II (BGG) from Pentex (23). The normal human serum pool consisted of over 50 individual samples and was donated by the Department of Clinical Chemistry at Scripps Clinic and Research Foundation. Serum concentrations of hemopexin, albumin, and transferrin were measured by radial immunodiffusion (6).

Rabbit anti-BGG antiserum was a gift of Dr. W. O. Weigle (24). Antisera to albumin, hemopexin, and transferrin were developed in goats or sheep. The monospecificity of our anti-albumin antiserum was tested by analyzing the dissociated antigen-antibody precipitates with polyacrylamide gel electrophoresis. The ${ }^{14} \mathrm{C}$-labeled proteins of one liver tissue culture were incubated with antialbumin and the immune precipitate was dissolved by incubation at room temperature for $48 \mathrm{hr}$ in $1 \%$ sodium dodecyl sulfate with $10 \mathrm{M}$ urea. The solution was mixed with $20 \mu \mathrm{l}$ bromophenol blue, applied on $5 \%$ polyacrylamide gel containing $0.1 \%$ sodium dodecyl sulfate, and electrophoresed in $0.1 \mathrm{M}$ Tris with $0.1 \%$ sodium dodecyl sulfate, $\mathrm{pH} 8.1$, for $90 \mathrm{~min}$. The gels were exhaustively washed with $10 \%$ trichloroacetic acid ( $36 \mathrm{hr}$ ), stained with $0.025 \%$ Coomassie blue $(8-10 \mathrm{hr})$ and destained with $7 \%$ acetic acid $(48$ hr). The gels were sliced into eight fractions, air dried, oxidized (Packard Tri-Carb sample oxidizer model 305 (25)) and counted (Packard Tri-Carb liquid scintillation specrometer model 3375 (25)) by Dr. L. E. Vickery (26). Approximately $90 \%$ of the total ${ }^{14} \mathrm{C}$ resided in the albumin fraction. Because the amounts of $\left[{ }^{14} \mathrm{C}\right]$ hemopexin and $\left[{ }^{14} \mathrm{C}\right]$ transferrin in the culture fluids were insufficient, we verified the monospecificity of anti-hemopexin and anti-transferrin by immunoelectrophoresis and double diffusion in agar.

\section{MEASUREMENT OF ${ }^{14} \mathrm{C}$-AMINO ACID INCORPORATION}

To 5-50- $\mu$ l aliquots of culture supernatant, $50 \mu 1$ normal human serum as carrier protein were added and the nonspecific radioactivity was precipitated by addition of equivalent amounts of $R G G$ and anti-BGG. The mixture was incubated $37^{\circ}$ for $30 \mathrm{~min}$, at $4^{\circ}$ overnight, and centrifuged at $1,200 \times g$ for $30 \mathrm{~min}$ at $4^{\circ}$. The supernatants were then used for precipitation with the monospecific antisera added to antibody excess. The reaction mixtures were incubated and centrifuged as described above. The radioimmune precipitates (RIP) were washed three times with phosphate-buffered saline, dissolved in $0.1 \mathrm{ml} 3 \mathrm{~N} \mathrm{NaOH}$, kept at $56^{\circ}$ for $1 \mathrm{hr}$, mixed with $1 \mathrm{ml}$ Beckman Bio-Solv no. 2 (27) and poured into scintillation vials. Tubes were rinsed once with $2 \mathrm{ml} \mathrm{MeOH}$ and three times with $2 \mathrm{ml}$ toluene fluor (2,5-diphenyloxazole, $4 \mathrm{~g}$ /liter; 1,4-bis-2-[(4-methyl-5-phenyloxazolyl)]benzene, $50 \mathrm{mg} /$ liter in dry toluene). All rinses were added to the scintillation vials and the radioactivity was measured to a $5 \%$ error factor in a Beckman $\beta$-scintillation counter. ${ }^{14} \mathrm{C}$ counts below twice background (54 
cpm) were not considered significant. Results were expressed as counts per minute per microliter of the original culture fluid, where:

$$
\text { RIP cpm } / \mu \text { l culture fluid }=\frac{\text { RIP cpm }- \text { background cpm }}{\mathrm{A} \times \mathrm{B}}
$$

with $\mathrm{A}=$ microliters of culture fluid used for the BGG-anti-BGG reaction; $\mathrm{B}=$ fraction of the supernatant ( $\mathrm{BGG}$-anti-BGG reaction mixture after removal of the precipitate) used for RIP with monospecific antiserum. Radioactivity of total protein was determined from the $95 \%$ ethanol precipitate of $10-\mu$ l aliquots of the culture supernatants. The ${ }^{14} \mathrm{C}$ content of each immunoprecipitate was calculated as the percentage of total protein for each culture fluid, i.e.

$\%$ total protein $=(\mathrm{RIP} \mathrm{cpm} / \mu \mathrm{l})(95 \%$ ethanol precipitate $\mathrm{cm} / \mu \mathrm{l})$

\section{RESULTS}

Serum concentrations of hemopexin, transferrin, and albumin were measured for 12 fetuses between 14 and 36 weeks of gestational age. Hemopexin levels ranged from 7 to $64 \mu \mathrm{g} / \mathrm{ml}$. These values are less than $10 \%$ of those in adults $(500-1,000$ $\mu \mathrm{g} / \mathrm{ml}$ ) (7). Transferrin levels ranged from 280 to $928 \mu \mathrm{g} / \mathrm{ml}$, approximately $50 \%$ of adult values. Albumin levels ranged from 13 $\mathrm{mg} / \mathrm{ml}$ up to $59 \mathrm{mg} / \mathrm{ml}$, which is similar to values found by us and others in adults $(10,16)$. In general, the serum concentration of the three proteins increased with advancing gestational age. No correlation existed, however, between the serum concentrations of hemopexin, transferrin, and albumin at any given time.

Tissue culture fluids from 10 placentas, 8 thymuses, and 5 colons were analyzed for production of albumin, transferrin, and hemopexin. RIP was first carried out with antisera not absorbed with fetal cells. Large amounts of nonspecific ${ }^{14} \mathrm{C}$ counts were precipitated with the monospecific antisera in spite of a preceding precipitation with BGG-anti-BGG. Similar results were observed by Urban et al. (18). Absorption of the antisera with intact cells of placenta, liver, thymus, and colon eliminated the nonspecific ${ }^{14} \mathrm{C}$ counts without significantly reducing the specific ${ }^{14} \mathrm{C}$ counts in the RIP. Results before and after absorption of the antisera are tabulated in Table 1 for one representative experiment from the tissue culture of placenta, thymus, colon, and liver. The results reveal that of these organs, only the liver synthesizes hemopexin, transferrin, and albumin.

The ${ }^{14} \mathrm{C}$ content in the RIP for albumin and hemopexin were similar before and after two absorptions with liver cells but those for transferrin became insignificant. Seventy-five per cent of the ${ }^{14} \mathrm{C}$ counts in the culture fluid of liver tissue fragments resided in protein of which $38 \%$ was albumin and $4.3 \%$ was hemopexin. In Table 2, results are listed from RIP obtained with absorbed antisera for four other hepatic cultures. The $\left[{ }^{14} \mathrm{C}\right]$ albumin accounted for $22-73 \%$ and the $\left[{ }^{14} \mathrm{C}\right]$ hemopexin for $1.1-4.2 \%$ of the total ${ }^{14} \mathrm{C}$-labeled proteins. In each instance, the ${ }^{14} \mathrm{C}$ content of the RIP for transferrin was below $1 \%$ of the total ${ }^{14} \mathrm{C}$-labeled protein.

\section{DISCUSSION}

We demonstrated the incorporation of isotope-labeled amino acids into hemopexin, albumin, and transferrin by fetal liver tissue in vitro. The immunoprecipitation method used enabled us to compare relative amounts of synthesis for these proteins. The fact that these proteins are produced by the fetal liver had been shown previously by radioautography (1).

Protein concentrations in fetal sera from 14 to 36 weeks of gestational age were similar to adult values for albumin (10): about $50 \%$ of adult values for transferrin, but less than $10 \%$ of adult values for hemopexin (7). The fetal serum concentrations do not reflect the relative amounts of synthesis of these proteins by the
Table 1. Immunoprecipitation of ${ }^{14} \mathrm{C}$-labeled albumin, transferrin, and hemopexin synthesized by fetal cultures

\begin{tabular}{|c|c|c|c|c|}
\hline \multirow[b]{2}{*}{ Organ } & \multirow{2}{*}{$\begin{array}{l}\text { Fetal age, } \\
\text { wk }\end{array}$} & \multirow[b]{2}{*}{ Antibody } & \multicolumn{2}{|c|}{$\begin{array}{l}\text { Proteins precipitated, } \\
\qquad \mathrm{cpm} /\left.\mu\right|^{1,2}\end{array}$} \\
\hline & & & Unabsorbed & Absorbed $^{3}$ \\
\hline \multirow[t]{3}{*}{ Placenta } & 15 & Anti-albumin & 240.0 & $<\mathrm{BK}^{4}$ \\
\hline & & Anti-transferrin & 40.4 & BK \\
\hline & & Anti-hemopexin & 158.0 & BK \\
\hline \multirow[t]{3}{*}{ Thymus } & 15 & Anti-albumin & 74.4 & BK \\
\hline & & Anti-transferrin & $\mathrm{BK}$ & BK \\
\hline & & Anti-hemopexin & 81.2 & $\mathrm{BK}$ \\
\hline \multirow[t]{3}{*}{ Colon } & 18 & Anti-albumin & 490.0 & BK \\
\hline & & Anti-transferrin & 118.0 & BK \\
\hline & & Anti-hemopexin & 371.6 & BK \\
\hline \multirow[t]{3}{*}{ Liver } & 18 & Anti-albumin & $1,912.0$ & 1,900 \\
\hline & & Anti-transferrin & 86.9 & BK \\
\hline & & Anti-hemopexin & 272.3 & 212.3 \\
\hline
\end{tabular}

${ }^{1}$ Values are the average of two determinations.

${ }^{2}$ Culture supernatants were subjected to a bovine $\gamma$-globulin Fr II (BGG)-anti BGG precipitation before precipitation with the specific antisera. The ${ }^{14} \mathrm{C}$ content of the $\mathrm{BGG}$-anti-BGG precipitates ranged from 115 to $300 \mathrm{cpm} / \mu 1$ culture fluid.

${ }^{3}$ Each antiserum was absorbed with whole fetal cells of the respective organ.

4 BK: background (values twice background counts per minute were considered significant).

Table 2. Immunoprecipitation of ${ }^{14} \mathrm{C}$-labeled proteins in fetal liver culture fluid

\begin{tabular}{clrc}
\hline Fetal age, wk & \multicolumn{1}{c}{ Antibody $^{1}$} & $\mathrm{cpm} / \mu \mathrm{l}^{2}$ & $\%^{3}$ \\
\hline \multirow{2}{*}{15} & Anti-albumin & $1,068.6$ & 35.30 \\
& Anti-transferrin & 19.8 & 0.66 \\
& Anti-hemopexin & 33.1 & 1.10 \\
15 & Anti-albumin & $1,590.8$ & 43.0 \\
& Anti-transferrin & $<\mathrm{BK}^{4}$ & \\
& Anti-hemopexin & 154.2 & 4.2 \\
16 & Anti-albumin & $1,121.5$ & 22.14 \\
& Anti-transferrin & $<\mathrm{BK}$ & \\
& Anti-hemopexin & 57.0 & 1.12 \\
& Anti-albumin & $2,690.0$ & 72.9 \\
& Anti-transferrin & 27.6 & 0.75 \\
& Anti-hemopexin & 150.8 & 4.09 \\
\hline
\end{tabular}

${ }^{1}$ Each antiserum was absorbed with whole fetal liver cells.

${ }^{2}$ Average of duplicate determinations.

${ }^{3}$ Percentage of total ethanol-precipitable counts per minute; more than $60 \%$ of the total radioactivity in the culture fluid was ethanol precipitable.

${ }^{4} \mathrm{BK}$ : background (values twice background counts per minute were considered significant.

liver observed in our in vitro data. Alternate sites of synthesis may be the reason for the substantial serum transferrin levels (17). The very low serum hemopexin levels encountered imply either a low rate of incorporation of radiolabeled amino acids into hemopexin or rapid catabolism. The first possibility appears to be excluded since hemopexin comprised about $4.0 \%$ of the total ${ }^{14} \mathrm{C}$-labeled protein. There is probably no preferential incorporation of $\left[{ }^{14} \mathrm{C}\right]$ leucine and $\left[{ }^{14} \mathrm{C}\right]$ isoleucine into hemopexin, for the content of these amino acids is similar in hemopexin, albumin, and transferrin (13). The relative amounts of hemopexin and albumin produced by the human fetal liver are similar to those recently found in tissue cultures of fetal and adult rat liver tissues in which the proteins 
were determined quantitatively (3). Therefore, the very low human fetal serum concentration of hemopexin observed probably does not reflect a decreased rate of synthesis but rather an increased rate of turnover of this protein in the fetus as compared with the adult.

\section{SUMMARY}

Protein concentrations in human fetal sera from 14 to 36 weeks of gestational age were similar to adult values for albumin, approximately half for transferrin, and less than $10 \%$ for hemopexin.

Culture fluids of fetal tissue from 10 placentas, 8 thymuses, and 5 colons were analyzed for production of albumin, transferrin, and hemopexin. Immunoprecipitates with absorbed antisera indicate that these organs do not synthesize the three proteins. By contrast, five culture supernatants of fetal liver tissue showed significant synthesis of albumin and hemopexin. Sixty per cent of the ${ }^{14} \mathrm{C}$ counts in the culture fluids resided in protein, $22-73 \%$ of total protein was albumin, 1.1-4.5\% was hemopexin, and less than $1 \%$ was transferrin.

\section{REFERENCES AND NOTES}

1. Gitlin, D., and Biasucci, A.: Development of $\gamma \mathrm{G}, \gamma, \gamma \mathrm{M}, \beta_{\mathrm{AC}} / \beta_{1 \mathrm{~A}}$, C'l esterase inhibitor, ceruloplasmin, transferrin, hemopexin, haptoglobin, fibrinogen, plasminogen, $\alpha_{1}$-antitrypsin, orosomucoid, $\beta$-lipoprotein, $\alpha_{2}$-macroglobulin, and prealbumin in the human conceptus. J. Clin. Invest., 48: 1433 (1969).

2. Hrkal, Z., and Muller-Eberhard, U.: Partial characterization of the heme-binding serum glycoproteins rabbit and human hemopexin. Biochemistry, 10: 1746 (1971).

3. Kida, S., and Muller-Eberhard, U.: A radioimmunoassay employing polyethylene glycol (PEG) for hemopexin, albumin, and haptoglobin. Immunochemistry, 12: 97 (1975)

4. Kohler, P. F.: Maturation of the human complement system. I. Onset time and sites of fetal C1q, C4, C3, and C5 synthesis. J. Clin. Invest., 52: 671 (1973).

5. Lane, R. S., Rangeley, D. M., Liem, H. H., Wormsley, S., and Muller-Eberhard, U.: Plasma clearance of ${ }^{125}$ I-labelled haemopexin in normal and haem-loaded rabbits. Brit. J. Haematol., 25: 533 (1973)

6. Mancini, G., Carbonara, A. O., and Heremans, J. F.: Immunochemical quantitation of antigens by single radial immunodiffusion. Immunochemistry, 2: 235 (1965).

7. Muller-Eberhard, U.: Hemopexin. New Engl. J. Med., 283: 1090 (1970).

8. Muller-Eberhard, U., Bosman, C., and Liem, H. H.: Tissue localization of the heme-hemopexin complex in the rabbit and the rat as studied by light microscopy with the use of radioisotopes. J. Lab. Clin. Med., 76: 426 (1970).

9. Muller-Eberhard, U., and Liem, H. H.: Hemopexin, the heme-binding serum $\beta$-glycoprotein. In: Structure and Function of Plasma Proteins, Vol. 1, p. 35 (Plenum Press, London, 1974).
10. Muller-Eberhard, U., Liem, H. H., Mathews-Roth, M. M., and Epstein, J. H.: Plasma levels of hemopexin and albumin in disorders of porphyrin metabolism. Proc. Soc. Exp. Biol. Med., 146: 694 (1974).

11. Muller-Eberhard, U., and Morgan, W. T.: Porphyrin binding proteins in serum. Ann. N.Y. Acad. Sci., in press.

12. Muller-Eberhard, U., Yam, L., Tavassoli, M., Cox, K., and Ozols, J.: Immunohistochemical demonstration of cytochrome $b_{5}$ and hemopexin in rat liver parenchymal cells using horseradish peroxidase. Biochem. Biophys. Res. Commun., 61: 983 (1974).

13. Schultze, H. E., and Heremans, J. F.: In: Molecular Biology of Human Proteins, Vol. 1, p. 173 (Elsevier Publishing Company, New York, 1966).

14. Sears, D. A.: Disposal of plasma heme in normal man and patients with intravascular hemolysis. J. Clin. Invest., 49: 5 (1970).

15. Seery, V. L., and Muller-Eberhard, U.: Binding of porphyrins to rabbit hemopexin and albumin. J. Biol. Chem., 248: 3796 (1973).

16. Takeda, Y., and Reeve, E. B.: Studies of the metabolism and distribution of albumin with autologous $\mathrm{I}^{131}$-albumin in healthy men. J. Lab. Clin. Med., 61 : 183 (1963).

17. Thorbecke, G. J., Liem, H. H., Knight, S., Cox, K., and Muller-Eberhard, U.: Sites of formation of the serum proteins transferrin and hemopexin. J. Clin. Invest., 52: 725 (1973).

18. Urban, J., Zimber, P., and Schreiber, G.: Immunoprecipitation is inappropriate for the isolation of radiochemically pure albumin from tissues. Anal. Biochem., 58: 102 (1974).

19. Wochner, R. D., Spilberg, I., lio, A., Liem, H. H., and Muller-Eberhard, U.: Hemopexin metabolism in sickle cell disease, porphyrias, and control subjects; effects of heme injection. New Engl. J. Med., 290: 822 (1974).

20. University of Colorado, Denver, Colo.

21. La Mirada, Calif.

22. Marburg, Germany.

23. Research Products Division, Miles Laboratories, Kankakee, Ill.

24. Department of Immunopathology, Scripps Clinic and Research Foundation, La Jolla, Calif.

25. Packard Instrument Co., Downers Grove, Ill.

26. Department of Chemistry, University of California, Berkeley, Calif.

27. Beckman Instruments, Inc., Fullerton, Calif.

28. We wish to thank Dr. P. Kohler (20) for the culture fluids, and Dr. S. G. Kellogg, and Mrs. E. P. Fornataro, Department of Obstetrics and Gynecology, University Hospital, San Diego, California, for providing tissues of deceased fetuses.

29. Dr. Ursula Muller-Eberhard is a recipient of Research Career Development Award 5-K3-AM-16,923 from the National Institute of Arthritis and Metabolic Diseases, United States Public Health Service.

30. Dr. Thomas P. Conway is a recipient of a United States Public Health Service Postdoctoral Fellowship from the Institute of Child Health and Human Development (HD-53442)

31. This work was supported by research grants from the National Heart Institute (HE-08660), from the Institute of Child Health and Human Development (HD-04445), and from the Institute of Arthritis and Metabolic Diseases (AM/HL-16737).

32. Requests for reprints should be addressed to: U. Muller-Eberhard, M.D., Department of Biochemistry, Scripps Clinic and Research Foundation, 476 Prospect St., La Jolla, Calif. 92037 (USA).

33. Accepted for publication February 25, 1975. 